\title{
Peculiarities of Social and Legal Regulation of Internet Relations
}

\author{
Alexander V. Mal'ko \\ and Alina S. Anisimova* \\ Saratov Branch of the Institute of State \\ and Law of the RAS \\ 135 Chernyshevskogo Str., Saratov, 410028, Russia
}

Received 22.01.2016, received in revised form 17.02.2016, accepted 20.06.2016

The present article studies peculiarities of legal regulation of Internet relations in regard with other social norms, which include the following: first of all, it is a new scope of law; secondly, it requires a co-regulation mechanism; thirdly, it "expands" the objective right beyond into the scope of social relations in the virtual space; fourthly, there are requirements (precepts) of international law; fifthly, it depends on the technical norms and standards of the web; sixthly, the parties it includes are specific; seventhly, the relations between users are mediated.

The mentioned peculiarities require the review of the currently established legal opinions, theoretical and legal values including the mechanism of legal regulation of Internet relations.

Keywords: legal regulation mechanism, the Internet, virtual space, Internet relations.

DOI: 10.17516/1997-1370-2016-9-8-1857-1862.

Research area: law.

With the modern global informatisation, telecommunication technologies, where the Internet occupies a specific place, expand to all spheres of human life.

The universal multipurpose use of the Internet begins to determine the pattern of social life: in politics, dictators' technologies of appeal are replaced with spreading information in the Internet; economics faces e-commerce, and, therefore, intellectual property problems; in cultural and social life we observe the loss of some national self-identification elements. In general, the processes of human communication become simpler, but the space for it undergoes some changes.

In the Internet people can socialize despite the distance between them. Information is immediately brought to the masses, and in a moment it becomes common, spreads and raises discussions. A person lets the whole world in his home using a computer or other technologies. This form of relations forms more than just a new context of culture; it develops a new kind of social relations called Internet relations.

This term refers to the part of social relations, which develops for the satisfaction of one's needs

(C) Siberian Federal University. All rights reserved

* Corresponding author E-mail address: igp@sgap.ru 
in the Internet as a phenomenon of social life, separated due to the technical progress.

Internet relations are constantly evolving; at a certain stage, they require some legal regulation. It is worth mentioning that the existing researches do not pay enough attention to the mechanism of legal regulation of Internet relations. Moreover, the absence of approaches to theoretical legal issues applicable to technical progress, and the actual establishment of such approaches by law make a negative impact on legal regulation itself. For this reason, let us study the peculiarities of the mechanism of legal regulation of the said relations.

Firstly, such mechanism manifests itself in the deliberate influence on the social relations developing in the new scope of law, the Internet.

"Merging" naturally with the general trends of various spheres of social life, the Internet generates a new artificial reality, alternative to the real one. Constructed by man, this space gradually substitutes the objective reality, where it is mainly referred to as virtual reality, which exists "here" and "now" under its own laws of time and space. Moreover, the life virtualization processes gradually fill administrative activity with its virtual content, creating prerequisites for the fundamental transformation of the state administration system ${ }^{1}$. For instance, "electronic government" programmes have gained priority in the development strategy of culturally and industrially developed countries, including Russia. The common idea of the virtual reality phenomenon facilitates the creation of a new approach: it is not computerization of life that virtualizes the society, but virtualization of society that computerizes life.

Secondly, in the mechanism of legal regulation of Internet relations an important place is occupied by co-regulation, i.e. the combination of self-regulation and normative regulation. In the process of the Internet development its users have been controlling their activity on their own, on the basis of an unstructured corpus of technical and other rules (particularly, "Acceptable use policy") ${ }^{2}$. However, the rules and standards contained in the documents are not more than means for selfdiscipline and can be used as reference material. The Internet provides people with a great scope of opportunities: socialization, entertainment, purchase and sale, search of information etc. Such types of interaction are similar to any other type of social contacts, though they have their own peculiarities. Consequently, all main communities and phenomena existing in the real society may have their "projections" in the virtual world. Besides, it has some disadvantages, such as violation of rights, various offences, organized crime, extremism, i.e. situations threatening the health, life of people, and their constitutional freedoms, which cannot be resolved without any legal regulations. In view of the foregoing, both virtual and real world need certain legal restrictions.

Self-regulation may be a useful tool, however, in the issues evoking some response from the society (such as policy of the Internet content control) relying on it is a risk.

Of course, on one hand, a person may freely use social networks and other Internet resources where the principles of morality are still applicable, but as soon as he neglects the rights of other people, the state has to interfere ${ }^{3}$.

Thirdly, the legal regulation mechanism slowly "expands" the objective rights beyond the scope of social relations into the virtual space.

Almost every issue of the Internet relations regulation has its legal aspects, but the legal base for the control over the evolving Internet is just beginning to develop. The Internet evolves fast and easily, and it is still just another place for people's activity. Therefore, any existing legal regulations may be applied to the Internet as well. 
Legal activity on the regulation of Internet relations is being launched. However, social relations are a dynamic phenomenon, and legal regulations often drag behind the current changes. It becomes evident today when the developing technology changes the social reality much faster than the legislation can react to it. According to S.S. Khoruzhiy, virtual reality may be described as a multi-modus being, i.e. a being, allowing for a variety of options and scenarios ${ }^{4}$. The speed and volume of international communication in the Internet prevent efficient application of legal regulations. Moreover, in some situations the laws become outdated before they are enacted.

However, in a number of cases the legal regulations existing in the real world need modification to be applied to the said relations with regard to the technical and social properties of the Internet.

Fourthly, the analysed mechanism has to contain the requirements (precepts) of international law, as the Internet influences more than just personal relations between people, but also international relations, being a space which exists beyond the territory of a given state or a region, formed in the process of interaction.

As remarked by D. Spar, it is a truly global medium, where communications discreetly cross borders, connect people and markets in new ways, destructing the common definition of national borders $^{5}$. Therefore, legal regulation of Internet relations shall rely on the concluded international treaties and agreements.

One of the reasons of such interaction is, first of all, the need for security of the Internet users, which may only be achieved on the international level.

Every year the number of offences in the Internet increases both in Russia and abroad. The Interpol evaluates the growth of crime in the Internet as the fastest in the world ${ }^{6}$. The most popular Internet crimes are: fraud, account tampering and theft of passwords, illegal disclosure of personal data, propagation of pornography. Thus, in the operation Pest, aimed at identification of the persons engaged in propagation of child pornography, carried out by K Department of the Russian Police, 319 criminal cases were initiated. Besides that, as a result, 4260 users from 70 countries of the world involved in such offence were found?

The statistics show that crime in the virtual space is a relatively new negative phenomenon which has already become ingrained in our legal life and requires revision and change of different legal constructions.

As fairly noticed by D.A. Medvedev, it is required to enforce the role played by the world community in the administration of the Internet and development of global policy in this field. It should be done under the aegis of the leading international institutions including the UN, relying on the International Telecommunication Union as a designated institution. In the future this organization can be authorized to develop international legal standards and regulations for the administration of the Internet. Such organization could also coordinate the designated international bodies ${ }^{8}$.

In the view of the above, normal functioning of the Internet requires reasonable combination of national and international legal requirements, as well as interaction between the states and coordination of their effort in regulation of Internet relations.

Fifthly, the mechanism of legal regulation of Internet relations is closely associated with the technical norms and standards of the web.

The Internet is a specific multilevel system, with its primary element being telecommunication lines, satellite lines, and network access systems. The next level is addressing space, domain names, domain titles. And, finally, over these levels there is a superstructure which provides us with all the 
known opportunities: services, search engine, websites, social networks, mail systems, news portals etc.

Therefore, a user's access to the Internet is provided due to efficient and uninterrupted work of the lower levels, creating technical conditions for the "entering" the virtual space as such.

Particularly, the technical component of the Internet is provided by:

1. International Engineering Task Force (IETF): an open international community of developers, scientists, network operators and providers founded in 1986 to develop protocols and architecture of the Internet. Technical work is done in work groups specializing in certain fields (e.g., the issues of routing, data transportation, security etc.).

2. Internet Society (ISOC): international professional organization (existing in 180 countries of the world) engaged in developing and providing access to the Internet ${ }^{9}$. It takes part in solving a wide range of issues including policy, administration, technology and development of the Internet. The main objective of the organization is to provide reliable uninterrupted access to the Internet for every present user and for the next one billion of users.

3. ICANN: a non-profit organization responsible for the global coordination of the unique elements of the Internet, i.e. distribution of domain names and domain titles (now there are around 250 country domain names). ICANN exists to develop and ensure stability, security and fail safety of the world wide web, as well as to create new programmes of the top-level domains.

4. Coordination Centre for the National Domain of the Internet: administrator of the top-level national domains RU and РФ. Acting as a national registrar, the coordination centre carries out various projects for the development and expansion of the Internet in
Russia in favour of Russian and global Internet communities $^{10}$.

Therefore, the bodies that deal with creation and implementation of technical facilities play the major role in the work of the Internet on both international and domestic levels.

However, no projects or initiatives can be run without consistent legal support. There is an actual need for the agreements and standards, which would regulate the influence of telecommunications on Internet relations. Even though these bodies are public and self-regulated, they also include political officials who struggle to implement and establish the latest formulations in the legislation.

For instance, after the invention of the Wi-Fi wireless communication standard and its popularization around the state, the Resolution of the Government of the Russian Federation No. 758 dated July 31, 2014 was issued. It allowed access to public Internet hotspots (where a user may access the Internet using a public computer, e.g. at a computer club, Internet café, Russian Post offices etc.) only after user identification. It means that the operator needs to record the user's full name confirmed by his/her ID ${ }^{11}$.

According to the introduced amendments, any public body which provides Internet access with its own hardware, shall keep a visit register which may be provided to the law enforcement bodies if necessary. Therefore, if a user propagates prohibited content from an Internet café (incitement of violence, drug sales etc.) it is easier to identify and bring him/ her to justice. Similar regulations were enacted through a number of laws toughening up the counterterrorism measures.

It is the said interaction which creates the connection ensuring our right for socialization and information in the way we need, together with proper security. 
Sixthly, Internet relations are specific due to its constituent parties. Particularly, there is the Internet ecosystem term, which refers to the bodies and communities which facilitate the work and development of the Internet. They include general coordination organizations which deal with implementing open standards; global and local addressing organizations which ensure the addressing function, such as ICANN, as well as domain registers and registrars; operators, engineers and suppliers of the web infrastructure services, such as domain name service, network operators and Internet Exchange Points; Internet users; education facilities which create resources for the development and use of the Internet technologies; politicians and other persons engaged in development and management of local and global issues ${ }^{12}$.

Each of the Internet relations' parties occupies a certain niche. The Internet can be consistently developed only with the joint efforts of all these parties and the combination of their interests to keep it transparent, accessible and open.

Seventhly, relations of the Internet users are mediated, not direct.

According to Article 1253.1 of the Civil Code of the Russian Federation, an "information intermediary" is a person who transfers some data in the information and telecommunication network including the Internet, a person who provides the opportunity for the placement of some data or information required for getting the data through the information and telecommunication network; it is also a person who provides access to such data in a network.

Therefore, actual use of a website is impossible without an intermediary who provides sufficient technical conditions for the Internet source's visitors.

With that in mind, the information intermediaries are hosting providers, Internet providers and website administrators (domain owners), as they act as an intermediary link between subjects of Internet relations. The actions, rights and obligations thereof are the basis for the rights and obligations of the web users.

With the listed peculiarities in mind, we may define the mechanism of legal regulation of Internet relations as a system of legal tools for the arrangement of the relations occurring in the virtual space with the help of information technologies. It provides the apprehensive approach to legal, technical, social, economic and other issues concerning various aspects of functioning and evolution of the Internet.

\section{References}

Bannykh, G.A. (2008) Reality of Virtualisation of State Government, In Voprosy upravleniia [Administration Issues] (2).

Naumov, V. B. (2003) Organizatsionno-pravovye aspekty samoregulirovaniia v rossiyskom segmente seti Internet: predely $i$ vozmozhnosti [Organizational and Legal Aspects of Self-Regulation in the Russian Segment of the Internet: Limits and Opportunities], In Assotsiatsiya dokumental'noy elektrosviazi (10). p. 22-25.

Genprokuratura beriotsia za regulirovanie seti [General Prosecution Office Gets Down to Regulation of the Web], In Nezavisimyy informatsionnyy portal. URL: http://www.noi.md/ru/news id/29406 (accessed on November 01, 2015).

Khoruzhiy, S.S. (1997) Rod ili nedorod? [Genus or Under-Genus?], In Voprosy filosofii [Problems of Philosophy], (6). p 64.

Koniaev, S.N. (2000) Real'naia virtual'nost': granitsy nabliudatelia $v$ informatsionnykh prostranstvakh iskusstvenno sozdannykh mirov [Real Virtuality: Observer's Borders in the Information 
Spaces of the Artificial Worlds], In Kontseptsiia virtual'nykh mirov i nauchnoe poznanie [The Concept of Virtual Worlds and Scientific Cognition], Saint Petersburg.

Falaleev, M. (2016) Za mig do nazhatiia knopki, [A Moment Before the Button Is Pressed] In The Rossiyskaia Gazeta, February 52016.

18-y Natsional'nyy forum informatsionnoy bezopasnosti "Informatsionnaya bezopasnost' Rossii $v$ tsifrovuyu epokhu: novye vyzovy, ugrozy, resheniia": Ministerstvo vnutrennikh del Rossiyskoy Federatsii $\left[18^{\text {th }}\right.$ National Forum of Information Security "Information Security of Russian in the Digital Era: New Challenges, Threats, Solutions": Ministry of the Internal Affairs of the Russian Federation]. URL: https://mvd.ru/news/item/7167829 (accessed on February 04, 2016).

Medvedev, D.A. RF podderzhivaet sozdanie mezhdunarodnoy organizatsii po regulirovaniiu Interneta: Informatsionnoe agentstvo Rossii [The RF Supports Foundation of an International Internet Regulation Body: Information Agency of Russia] URL: http://tass.ru/ekonomika/2531411 (Accessed on January 10, 2016).

Internet Society. URL: http://www.internetsociety.org/ru (accessed on January 01, 2016).

Koordinatsionnyy tsentr natsional'nogo domena seti Internet [Coordination Centre TLD RU/PФ] URL: http://cctld.ru/ru/ (Accessed on January 04, 2016).

Postanovlenie Pravitel'stva Rossiyskoy Federatsii ot 31 iiulya 2014 g. № 758 g. [Resolution of the Government of the Russian Federation No 758 dated July 31, 2014], In The Rossiyskaya Gazeta, August 5, 2014.

Ekosistema Interneta: Internet Society [Ecosystem of the Internet: Internet Society] URL: http:// www.internetsociety.org/ru (accessed on January, 01 2016).

\title{
Особенности социально-правового регулирования интернет-отношений
}

\author{
А.В. Малько, А.С. Анисимова \\ Саратовский филиал Института государства и права РАН \\ Россия, 410028, Саратов, ул. Чернышевского, 135
}

В статье рассматриваются особенности правового регулирования интернет-отношений 8 связи с иныли социильными нормами. Среди них выделяются следующие: во-первых, новая сфера действия права; во-вторых, действует механизм сорегулирования; в-третьих, "развертывает» объективное право вовне в область общественных отношений в виртуальном пространстве; в-четвертых, наличие требований (предписаний) международного права; в-пятых, связь с техническими нормами и стандартами Сети; в-шестых, особый субъектный состав; в-седьмых, отношения между пользователями складываются через посредника.

Приведенные особенности приводят к переосмыслению ряда устоявшихся правовых взглядов, теоретико-правовых иченностей, включая и сам механизм правового регулирования интернетотномений.

Ключевые слова: механизм правового регулирования, Интернет, виртуальное пространство, интернет-отношения.

Научная спещиильность: 12.00.00 - юридические науки. 